Vol. 2 | No. 3 | 2021 | Hal. 180-187

\title{
PERLUASAN PANGSA PASAR PRODUK UMKM SELAMA PANDEMI COVID-19 MELALUI PEMANFAATAN MARKETPLACE
}

\author{
Dewi Diah Fakhriyyah*, Arista Fauzi Kartika Sari, Lucky Ayu Damayanti, Mardhani \\ Susilawati \\ Fakultas Ekonomi dan Bisnis, Universitas Islam Malang \\ *korespondensi email: dewi_df@unisma.ac.id
}

\begin{abstract}
ABSTRAK
Pandemi Covid-19 memberikan dampak di berbagai aspek, salah satunya yaitu aspek ekonomi. Menjadi suatu tantangan baru, khususnya bagi para pelaku UMKM agar bisa mempertahankan ekonomi di tengah pandemi saat ini. Tidak sedikit UMKM yang menjadi pasif bahkan terpaksa terhenti akibat terdampak pandemi Covid-19. Keputusan pemerintah dalam memberlakukan pembatasan kegiatan secara tidak langsung menyebabkan daya beli konsumen melemah, sehingga itu juga berdampak pada turunnya tingkat penjualan produkproduk UMKM, belum lagi jika mereka (pelaku UMKM) harus menghadapi persaingan pasar. Selain itu, yang menjadi kendala adalah tidak semua pelaku UMKM melek teknologi, sedangkan di masa pandemi seperti saat ini semuanya dijangkau serba online, khususnya para konsumen lebih memilih membeli kebutuhan mereka secara online. Maka dari itu, kami mencoba untuk membantu salah satu UMKM di Desa Sumbersekar, Kec. Dau, Kab. Malang, Jawa Timur, yaitu UMKM yang memproduksi telur asin dalam upaya meningkatkan penjualan dengan memperluas pangsa pasar melalui pemanfaatan marketplace. Pada tahap pertama, kami melakukan sosialisasi atau pengenalan terkait berbagai macam platform (marketplace) terkini beserta masing-masing keunggulannya. Pada tahap kedua, kami membantu pelaku UMKM dalam pembuatan akun merchant pada marketplace dan akun media sosial terkini yang dapat menunjang perluasan pangsa pasar serta memudahkan pelaku UMKM dalam mempromosikan produknya. Pada tahap ketiga, kami menjelaskan kepada pelaku UMKM tentang bagaimana cara mengelola akun marketplace dengan baik, serta pentingnya melakukan promosi atau iklan secara berkala guna meningkatkan engagement rate. Harapan kami, setelah melakukan berbagai tahapan di atas dapat membantu pelaku UMKM dalam meningkatkan penjualannya, serta mempertahankan usahanya di tengah pandemi covid-19.
\end{abstract}

Kata Kunci: pandemi covid-19; UMKM; marketplace; pangsa pasar; marketing

\section{PENDAHULUAN}

Munculnya pandemi covid-19 telah membawa perubahan terhadap dunia dengan berbagai tantangan yang tidak pernah terbayangkan sebelumnya. Di Indonesia, covid-19 telah menjangkiti sekitar 4.008 .166 orang (per tanggal 24 Agustus 2021) sejak kasus pertama diumumkan pada bulan Maret 2020 dan sebanyak 128.252 nyawa terenggut akibat terjangkit virus covid-19. Pemerintah terus melakukan upaya untuk mencegah dan memutus rantai penyebaran virus covid-19. Namun sayangnya, upaya tersebut secara tidak langsung juga menghambat kegiatan perekonomian dan berdampak pada tingkat kesejahteraan sosial. Setelah mencapai penurunan tingkat kemiskinan beberapa tahun 
belakangan ini, kini tingkat kemiskinan kembali meningkat setelah pandemi covid-19. (Smeru.or.id, 2021).

Pertumbuhan ekonomi yang memburuk sejak tahun 2020 tak terlepas dari daya beli masyarakat yang melemah selama pandemi. Kebijakan PPKM untuk mencegah penyebaran pandemi covid-19 menyebabkan terbatasnya mobilitas dan aktivitas masyarakat yang berdampak pada penurunan permintaan (Prihatiningtias et al., 2021; Purwanto, 2021).

Wabah covid-19 yang terjadi secara global termasuk di Indonesia telah memicu sentimen negatif terhadap berbagai lini bisnis, khususnya bisnis UMKM (Usaha Mikro Kecil dan Menengah) yang selama ini menjadi bagian terpenting dari sektor ekonomi di Indonesia. Dampak negatif akibat wabah covid-19 ini cukup menghambat pertumbuhan bisnis UMKM yang memerlukan ruang promosi terhalang dengan adanya kebijakan PPKM yang dianggap akan mampu mempercepat penanggulangan dan memutus rantai penyebaran virus covid19. Pandemi covid-19 ini membuktikan bahwa UMKM sangatlah berperan dalam perekonomian Indonesia. Sektor UMKM dianggap paling tinggi kerentanannya di masa pandemi ini, karena perputaran bisnis atau perdagangannya dilakukan setiap hari (Aliyani $\mathrm{dkk}, 2020)$.

Pandemi covid-19 ini sangat berdampak pada keberlangsungan bisnis UMKM. Berdasarkan hasil survei, sebanyak 96\% pelaku usaha atau UMKM mengaku telah merasakan dampak negatif pandemi covid-19 (sebanyak 1.785 koperasi dan 163.713 pelaku usaha UMKM). Sebanyak 75\% diantaranya mengalami dampak penurunan pendapatan atau penjualan yang cukup signifikan. Tidak hanya itu, sebanyak $51 \%$ pelaku usaha memprediksi bahwa bisnis atau usaha yang dijalaninya hanya akan bertahan hingga beberapa bulan kedepan saja. Sebanyak 67\% pelaku usaha mengalami ketidakpastian dalam memperoleh akses dana darurat, dan 75\% pelaku usaha tidak mengerti bagaimana membuat kebijakan atau strategi untuk mempertahankan bisnisnya di masa krisis seperti pandemi saat ini. Sementara itu, hanya 13\% pelaku usaha yang yakin karena mereka memiliki rancangan strategi dalam penanganan krisis dan solusi untuk mempertahankan bisnis atau usaha mereka (Soetjipto, 2020).

Meskipun di tengah pandemi covid-19, peluang bisnis UMKM tetap tidak terbatas dan apapun bidangnya tetap berpotensi, asalkan para pelaku UMKM memiliki ide kreatif, keahlian, dan keterampilan yang bisa dijual secara offline maupun online. Sementara, tantangan yang dihadapi oleh para pelaku UMKM adalah persaingan pasar yang menuntut mereka untuk harus terus berinovasi serta mengikuti perkembangan teknologi agar dapat tetap bertahan di tengah persaingan pasar (Marlinah, 2020). Apalagi saat ini daya beli masyarakat yang menurun dikarenakan berbagai bentuk pembatasan kegiatan, sehingga banyak masyarakat yang saat ini beralih ke pembelian secara digital (online). Dampaknya, banyak UMKM yang terhambat atau terhenti usahanya dikarenakan menurunnya penjualan dan selama ini masih bergantung pada penjualan secara offline, hal tersebut juga disebabkan karena masih minimnya pengetahuan teknologi dan mindset bahwa media digital atau online itu sulit dioperasikan.

Perkembangan teknologi yang sangat pesat saat ini ditandai dengan munculnya internet dan perkembangan teknologi berupa internet ini telah mengubah pola atau proses bisnis (Cahya, dkk (2021)). Dengan adanya internet, dapat mempermudah proses transaksi jual beli secara online atau sering kita sebut e-commerce. E-commerce merupakan suatu website yang menyediakan berbagai layanan transaksi online atau dapat juga diartikan sebagai suatu cara berbelanja atau berdagang secara online atau direct selling yang memanfaatkan fasilitas internet yang dapat menyediakan layanan get and deliver, sehingga e-commerce dapat mengubah semua kegiatan marketing sekaligus dapat memangkas atau 
meminimalisir berbagai biaya-biaya operasional untuk aktivitas perdagangan (Sudaryono, dkk, 2020).

E-commerce berperan sebagai media bisnis atau perdagangan yang cukup kompleks, yang terdiri dari penjualan, pembelian, dan pembayaran secara online. Saat ini pertumbuhan e-commerce cukup signifikan dikarenakan karena gaya masyarakat yang mulai beralih dari belanja offline menjadi cenderung belanja online (Nuraida,dkk 2018). Hal tersebut salah satunya terdapat dalam suatu sistem yang telah diciptakan sedemikian rupa seperti pada marketplace. Marketplace merupakan sebuah pasar digital yang menjajakan produk-produk dengan berbagai jenis produk dan label/merek dari berbagai vendor atau produsen, dimana marketplace ini sebagai perantara yang menghubungkan antara penjual dengan pembeli. Adanya berbagai macam marketplace seperti shopee, lazada, tokopedia, bahkan grab dan gojek yang dulunya hanya fokus di layanan transportasi kini dapat menjadi perantara antara penjual dan pembeli seperti yang tersedia pada fitur grabfood, grabmart, gofood, dan sejenisnya.

Bagi para pelaku UMKM, adanya marketplace saat ini dapat dijadikan sebagai suatu pilihan untuk memudahkan mereka dalam bertransaksi, memperluas pasar, melakukan promosi, hingga meningkatkan penjualan produk mereka. Tentunya dengan adanya berbagai macam platform e-commerce ini mempermudah para pelaku ekonomi, baik dari sisi penjual maupun konsumen atau pembeli. Namun tidak semua UMKM ataupun pelaku usaha memiliki pengetahuan atas pemanfaatan teknologi maupun marketplace.

Salah satu UMKM yang belum paham atas pemanfaatan teknologi dan marketplace ini adalah UMKM Telur Asin "A.N" milik Ibu Nuri dan suaminya yang telah dikelola selama kurang lebih 12 tahun yang berlokasi di Desa Sumbersekar, Kecamatan Dau, Kabupaten Malang. Selama pandemi Covid 19 ini mengalami penurunan penjualan yang drastis bahkan ternak bebeknya juga ikut hancur, sehingga untuk tetap bisa memproduksi telur asin, saat ini mereka mengambil telur bebek mentah dari tempat lain. Untuk pemasarannya sendiri, $\mathrm{Bu}$ Nuri hanya mempromosikan telur asin yang diproduksinya melalui media whatsapp business, dimana mayoritas konsumen atau pemesan telur asin hanya dari beberapa kalangan pelanggan setianya, sehingga jangkauan pasarnya masih terbatas. Diperlukan perubahan sistem penjualan dan pemasaran untuk mengatasi penurunan penjualan. Oleh karena itu, kami ingin melakukan sosialisasi dan edukasi pemanfaatan marketplace guna meningkatkan penjualan produk UMKM dan memperluas pangsa pasar.

\section{METODE}

Dalam kegiatan ini, yang menjadi objek kami adalah UMKM Telur Asin "A.N." (Sumbersekar) yang dikelola oleh Bu Nuri dan suaminya (sebagai subjek dalam kegiatan ini). Sebelumnya, kami telah melakukan survey mengenai UMKM-UMKM yang ada di Desa Sumbersekar. Kemudian, kami memutuskan untuk menerapkan rancangan program kami pada UMKM Telur Asin "A.N." (Bu Nuri, Desa Sumbersekar) karena kami merasa rancangan program yang kami susun cocok dengan UMKM tersebut, yang sama sekali belum pernah menggunakan marketplace (seperti shopee, grab(food), gofood (by gojek), dan sejenisnya)untuk memasarkan produknya, selain itu juga tempat dan proses produksinya cukup kondisional, sehingga kami juga bisa ikut serta dalam membantu proses produksi, dan tentunya baik dari pihak kami maupun pihak pelaku UMKM sama-sama merasa nyaman saat melakukan sharing.

Selanjutnya, kami melakukan sharing dengan pelaku UMKM yang bersangkutan, terutama mengenai keluhan yang dirasakan oleh pelaku UMKM akibat usahanya yang terdampak pandemi covid-19. Kemudian, kami lanjutkan dengan melakukan pengenalan atau sosialisasi, diantaranya: (1) Pengenalan berbagai macam platform (marketplace) yang 
saat ini banyak digunakan, serta menjelaskan keunggulan dari masing-masing platform; (2) Cara pembuatan akun merchant pada marketplace (shopee) dan akun media sosial (instagram) sebagai penunjang dalam memperluas pemasaran, serta membantu pelaku UMKM dalam mempromosikan produknya; (3) Cara mengelola akun merchant pada marketplace (shopee) dan akun media sosial (instagram) dengan baik dan benar, serta menyinggung tentang pentingnya melakukan iklan atau promosi secara berkala guna meningkatkan engagement rate.

Sosialisasi dan realisasi program dilaksanakan di rumah Ibu Nuri (pengelola UMKM) sekaligus tempat produksi telur asin, dan dalam rangkaian kegiatan kami tidak lupa untuk mematuhi protokol kesehatan, mengingat situasi pandemi covid-19 di tengah pelaksanaan kegiatan pengabdian masyarakat.

\section{HASIL DAN PEMBAHASAN}

Selama kami merealisasikan program kami terhadap UMKM Telur Asin "A.N." (Sumbersekar) ini, berikut hasil dan pembahasan yang dapat kami sampaikan, diantaranya:

\section{Pengenalan berbagai macam platform (marketplace) beserta masing-masing keunggulannya.}

Kami menyampaikan kepada Bu Nuri (selaku pengelola UMKM Telur Asin "A.N.”) mengenai berbagai macam jenis platform (marketplace) seperti shopee, lazada, grab(food), gofood (by gojek), dan sejenisnya. Kami menjelaskan bahwa saat ini banyak bisnis di bidang kuliner yang memanfaatkan platform tersebut, karena tentunya di situasi pandemi seperti saat ini, ditambah lagi pembatasan kegiatan atau mobilitas masyarakat (istilahnya PPKM), sebagai pelaku usaha tidak bisa mengandalkan penjualan produk secara konvensional atau offline saja. Hal tersebut dikarenakan daya beli konsumen yang melemah dan kecenderungan para konsumen untuk beralih ke belanja online.

Selain mengenalkan berbagai macam marketplace, kami juga menjelaskan masing-masing keunggulan dari marketplace tersebut. Mulai dari grabfood, gofood (by gojek), dan shopeefood (fitur terbaru dari shopee) yang dapat memudahkan dalam mempertemukan antara penjual dengan konsumen, hingga memperluas jangkauan konsumen (pelanggan), karena selama ini pemasaran produk telur asin hanya melalui whatsapp standar dan whatsapp business, dimana koneksi pelanggan hanya itu-itu saja. Untuk pengiriman luar kota, kami juga menjelaskan bahwa di platform seperti shopee juga menyediakan layanan Same Day Delivery, dimana layanan tersebut dapat memudahkan pengiriman produk ke luar kota dalam hitungan jam, produk dapat sampai di tangan pelanggan pada hari yang sama, sehingga tidak perlu khawatir, apalagi mengenai ketahanan telur asin yang diproduksi oleh Bu Nuri dan suaminya, karena pengolahannya sama sekali tidak menggunakan bahan pengawet.

Setelah kami mengenalkan dan menjelaskan berbagai macam platform (marketplace) dan keunggulannya, nampaknya Bu Nuri sebelumnya sudah sedikit tahu tentang platform-platform tersebut, salah satunya Shopeefood (hanya sekadar tahu bahwa saat ini banyak driver shopeefood, tidak hanya driver grabfood dan gofood) dan ada beberapa hal yang baru diketahui oleh Bu Nuri, salah satunya yaitu layanan Same Day Delivery (dari Shopee).

Namun sayangnya, Bu Nuri awalnya tidak tertarik untuk mendaftarkan usahanya dan memasukkan produknya ke dalam marketplace, karena ada beberapa hal yang perlu dipertimbangkan, seperti mengenai ketahanan produk, pengemasan, dan dari segi waktu juga, karena Bu Nuri dan suaminya juga menjalankan pekerjaan lain di luar memproduksi dan memasarkan telur asin, sehingga dikhawatirkan tidak dapat membagi 
waktu dan tidak ada yang mengurus pesanan ketika ditinggal bekerja. Di sisi lain, $\mathrm{Bu}$ Nuri masih khawatir jika tidak bisa mengoperasikan aplikasi atau mengelola akunnya, karena sebelumnya Bu Nuri juga pernah menawarkan produknya di media sosial facebook, tetapi karena akunnya tiba-tiba bermasalah dan tidak mengerti bagaimana cara mengatasinya, sehingga akun facebook itu sudah tidak bisa digunakan lagi. Oleh karena itu, Bu Nuri meminta untuk diberikan waktu untuk mempertimbangkan keputusannya apakah ingin mendaftarkan usahanya dan menawarkan produknya di marketplace atau tidak.

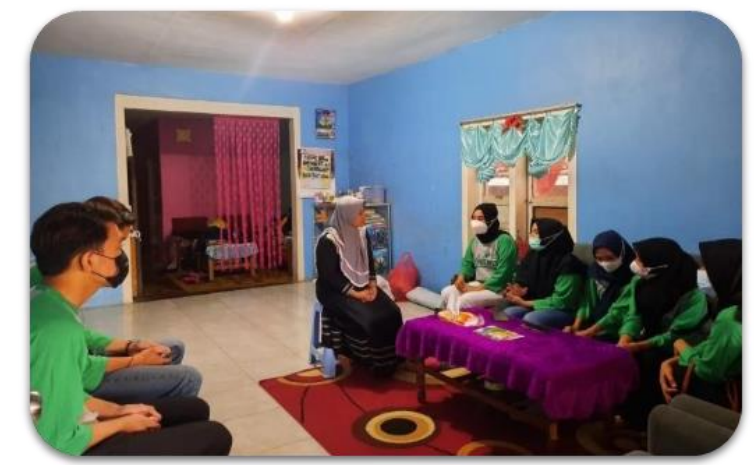

Gambar 1. Suasana diskusi atau sharing, serta melakukan pengenalan berbagai macam platform marketplace (Desa Sumbersekar)

\section{Pembuatan akun merchant pada marketplace shopee dan akun media sosial instagram.}

Setelah melalui berbagai pertimbangan, akhirnya Bu Nuri dan suaminya sepakat untuk mendaftarkan usahanya dan menawarkan produknya ke marketplace shopee dan kami juga menawarkan untuk membantu pembuatan akun media sosial instagram untuk menunjang keberlangsungan usaha, khususnya untuk media promosi atau iklan. Dengan kesepakatan itu, kami akhirnya mulai membantu pendaftaran akun merchant di shopee dengan mengaktifkan layanan Same Day Delivery dan dilanjutkan dengan pembuatan akun instagram (mode akun profesional/bisnis) untuk memudahkan Bu Nuri dan suaminya untuk mempromosikan produknya.

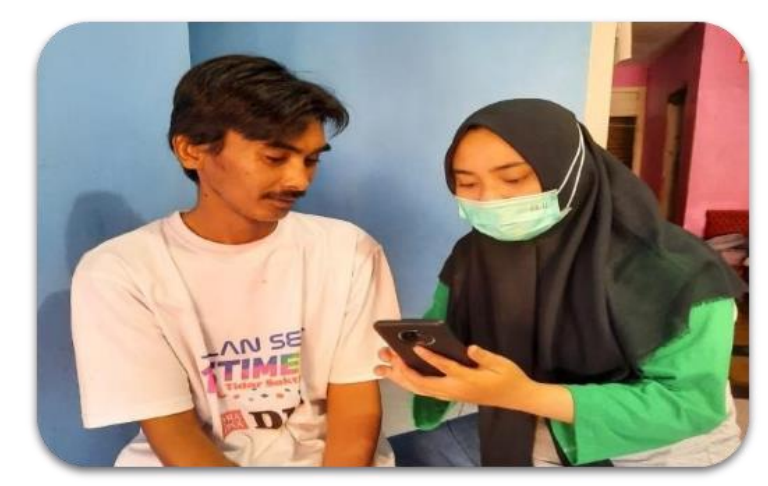

Gambar 2. Pembuatan akun merchant pada marketplace shopee dan akun media sosial instagram. (Desa Sumbersekar)

3. Pengelolaan/pengoperasian akun merchant pada marketplace shopee dan akun media sosial instagram, beserta edukasi pentingnya iklan atau promosi secara berkala.

Setelah pembuatan akun selesai, kami menjelaskan tentang bagaimana cara mengoperasikan dan mengelola akun dengan baik dan benar. Tetapi, tidak bisa dipungkiri bahwa $\mathrm{Bu}$ Nuri dan suaminya memiliki latar belakang keterbatasan pengetahuan tentang teknologi. Untuk jenis marketplace seperti shopee, nampaknya 
masih kesulitan. Oleh karena itu, kami lebih memfokuskan ke akun media sosial instagram. Namun, untuk media sosial instagram, kami juga menjelaskan bahwa di instagram ada istilah engagement rate.

Engagement rate merupakan sebuah sebutan yang sering digunakan dalam dunia digital marketing, khususnya social media marketing, seperti pada instagram, dimana engagement rate ini merupakan alat ukur keterlibatan followers atau pengikut dalam aktivitas media sosial (Ismail, 2020). Sehingga, untuk meningkatkan engagement rate perlu melakukan dan memperhatikan beberapa hal, seperti jam/waktu pengunggahan postingan, baik berupa foto, video (IGTV, Reels), pentingnya penggunaan hashtag, dan juga membuat instastory secara berkala (yang mengandung iklan atau promosi). Sehingga, selain membuat akun terkesan aktif, juga dapat meningkatkan engagement rate.

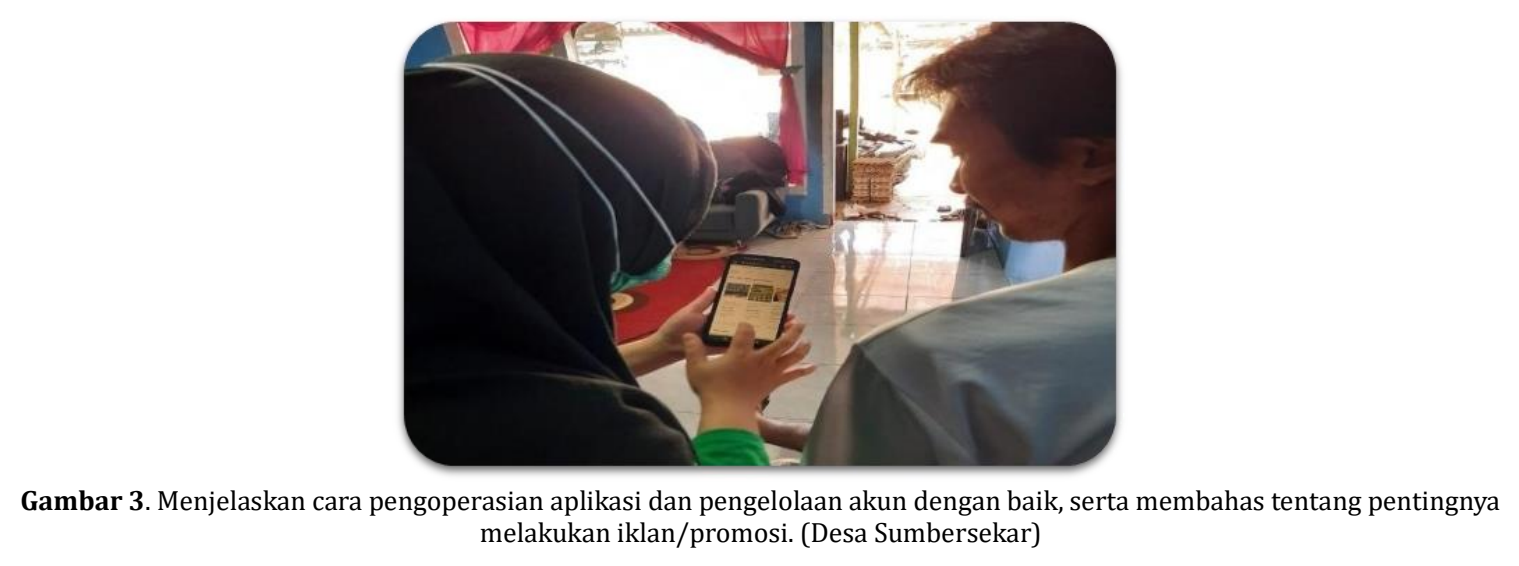

4. Kegiatan tambahan: Kami ikut serta dalam proses produksi telur asin.

Setelah rangkaian kegiatan, seperti diskusi atau sharing, pembuatan akun dan memberi arahan mengenai pengelolaan akun, kami diberikan kesempatan untuk ikut serta dalam proses produksi telur asin, kebetulan suami Bu Nuri telah mengambil persediaan telur bebek mentah di pengepul.

Kami ikut serta dalam membantu proses produksi, mulai dari pencucian telur bebek hingga tahap pengasinan. Disini kami merasa mendapatkan feedback berupa wawasan baru tentang bagaimana cara memproduksi telur asin, bagaimana menghasilkan telur asin yang berkualitas, dan perbedaan antara telur asin yang 100\% menggunakan bahan alami dengan telur asin yang menggunakan pengawet.

Telur asin yang diproduksi oleh $\mathrm{Bu}$ Nuri dan suaminya ini benar-benar menggunakan bahan alami, hanya dengan bantuan batu bata dan garam kasar yang dihaluskan. Untuk produksinya sendiri, Bu Nuri dan suaminya memproduksi hingga 400 butir telur asin bahkan lebih (jika ada pesanan dalam jumlah besar) dalam seminggu.

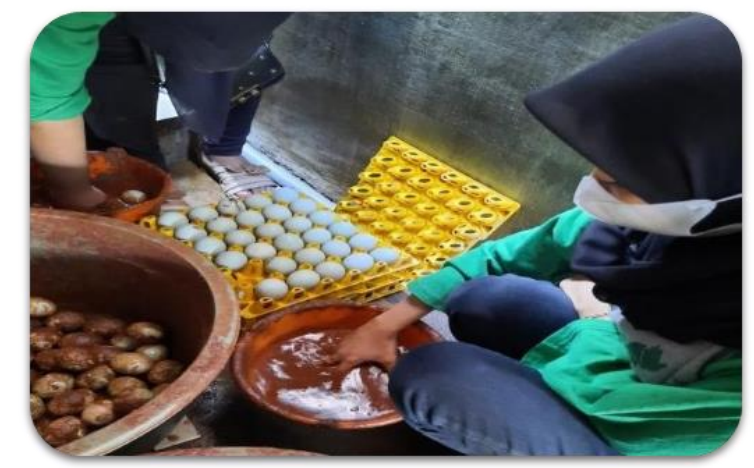

Gambar 4. Proses produksi telur asin (pencucian telur bebek mentah dan pengasinan telur). (Desa Sumbersekar) 


\section{KESIMPULAN}

Secara keseluruhan, kami telah melaksanakan kegiatan sesuai rancangan dan kami juga diberi kesempatan oleh $\mathrm{Bu}$ Nuri dan suaminya (selaku pengelola UMKM Telur Asin "A.N.") untuk ikut serta membantu sekaligus belajar dalam proses produksi telur asin. Mengenai pengenalan berbagai macam platform (marketplace), hingga pembuatan dan cara pengelolaan akun, dapat kami simpulkan bahwa pemahaman Bu Nuri dan suaminya mengenai teknologi, khususnya di bidang digital marketing masih terbilang cukup rendah, meskipun sebelumnya Bu Nuri pernah memasarkan produknya di media sosial facebook, bisa terbilang Bu Nuri hanya memahami hal-hal yang sangat mendasar dari sebuah media sosial. Jadi, ketika ada error atau masalah pada akunnya, Bu Nuri tidak begitu paham mengenai penyebab dan solusi untuk mengatasi masalah tersebut. Sehingga, untuk mulai memasarkan produknya di marketplace, awalnya Bu Nuri dan suaminya ragu, karena menganggap itu hal yang sepertinya cukup rumit, dan ada keraguan apakah bisa konsisten dalam mengelola akunnya, baik di marketplace shopee maupun akun media sosial instagramnya. Hingga pada akhirnya, Bu Nuri dan suaminya sepakat untuk mencoba membuat akun merchant di marketplace shopee dan akun media sosial instagram untuk menawarkan produknya, serta memperluas jangkauan konsumen.

Namun, di sisi lain, kami mengakui bahwa kami juga masih banyak kekurangan, sehingga kami merasa pelaksanaan kegiatan ini masih kurang maksimal. Keterbatasan waktu juga menjadi salah satu faktor penghambat kami dalam memaksimalkan kegiatan ini, karena Bu Nuri dan suaminya sama-sama memiliki kesibukan lain selain memproduksi dan menjual telur asin, sehingga kesempatan kami untuk datang ke lokasi dan menemui beliau secara langsung juga terbatas.

Meskipun begitu, kami berharap apa yang telah kami berikan dapat bermanfaat untuk $\mathrm{Bu}$ Nuri dan suaminya, dapat membantu beliau dalam meningkatkan penjualan telur asin untuk kedepannya (jangka panjang), karena memang beliau mengakui bahwa terhitung sejak awal pandemi (Maret 2020), pendapatannya menurun drastis, bahkan peternakan bebeknya juga ikut hancur. Maka dari itu, kami juga berusaha untuk tetap terus menjalin komunikasi, untuk memantau berbagai perkembangan kedepannya dan mungkin jika sewaktu-waktu beliau merasa kesulitan atau ada permasalahan pada akunnya, kami juga bersedia untuk membantu.

\section{UCAPAN TERIMA KASIH}

Ucapan terimakasih kami sampaikan kepada (1) Kepala Desa Sumbersekar, Bpk. Hasan Asyari, beserta jajarannya yang telah memberikan izin kepada kami untuk melaksanakan pengabdian masyarakat di Desa Sumbersekar; (2) Bu Fanda, yang telah menjadi perantara yang menghubungkan kami dengan para pelaku UMKM di Desa Sumbersekar; (3) Bu Nuri selaku pengelola UMKM Telur Asin "A.N." (Sumbersekar) yang telah memberikan kesempatan kepada kami untuk menjadikan UMKM-nya sebagai objek kegiatan kami dalam menyalurkan program yang telah kami rancang dengan harapan dapat membantu keberlangsungan usahanya.

\section{DAFTAR RUJUKAN}

Agus D., Fadhilla A., Asfarina Z., Hesthi S. (2021). Memanfaatkan Marketplace sebagai Media Promosi untuk Meningkatkan Penjualan di Tengah Pandemi Covid-19. Scientific $\begin{array}{lll}\text { Journal of } & \text { Reflection, 503-504. }\end{array}$ https://www.ojspustek.org/index.php/SJR/article/view/329

Aliyani Firdaus, S., Fadilah Ilham, I., Putri Aqidah, L., Aliyani Firdaus, S. ., Agung Dwi Astuti, S., \& Buchori, I. (2020). Strategi UMKM untuk Meningkatkan Perekonomian selama 
Pandemi Covid-19 pada saat New Normal. OECONOMICUS Journal of Economics, 5(1), 46-62. https://doi.org/10.15642/oje.2020.5.1.46-62

Cahya, A. D. ., Aqdella, F. A. ., Jannah, A. Z. ., \& Setyawati, H. . (2021). MEMANFAATKAN MARKETPLACE SEBAGAI MEDIA PROMOSI UNTUK MENINGKATKAN PENJUALAN DI TENGAH PANDEMI COVID-19. SCIENTIFIC JOURNAL OF REFLECTION : Economic, Accounting, Management and Business, 4(3), 503-510. Retrieved from https://ojspustek.org/index.php/SJR/article/view/329

Ismail, Ibnu. (2020). "Engagement Rate adalah : Pengertian, Faktor, dan Cara Mengukurnya”. Accurate. Diakses 30 Agustus 2021 pada https://accurate.id/marketingmanajemen/engagement-rate-

adalah/\#: :text=Engagement\%20rate\%20adalah\%20sebuah\%20sebutuan,dalam\% 20suatu\%20akun\%20media\%20sosial.

Marlinah, Lili. (2020). Peluang dan Tantangan UMKM dalam Upaya Memperkuat Perekonomian Nasional Tahun 2020 di Tengah Pandemi Covid-19. Jurnal Ekonomi, 22(2), 118-119. https://doi.org/10.37721/je.v22i2.644

Nuraida W., Mutaqin, AIS., Gunawan, A. (2018). Pengenalan dan Pemanfaatan E-Commerce untuk Pelaku UKM Wilayah Cilegon. Jurnal Pengabdian Dinamika, 5(1), 3.

Purwanto, Antonius. (2021). “Ekonomi Indonesia pada Masa Pandemi Covid-19 : Potret dan Strategi Pemulihan 2020-2021". Berita 27 Januari 2021. Kompaspedia. Diakses 25 Agustus 2021 pada https://kompaspedia.kompas.id/baca/paparan-topik/ekonomi-indonesia-padamasa-pandemi-covid-19-potret-dan-strategi-pemulihan-2020-2021

Prihatiningtias, Y. W., Prabandari, S. P., Cahaya, D. N., Kusumadewi, A. W., Anggraeni, O. L., Nisa, K., Rizkiyah, A., \& Arasy, F. H. (2021). Peningkatan pengetahuan aspek perpajakan pengelolaan produk pada kelompok UMKM dan kualitas Info Artikel Abstrak yang menyebabkan jatuhnya perekonomian nasional. Banyak usaha-usaha Mikro , Kecil , dan Menengah ( UMKM) dapat bertahan dan menjadi pemulih. Jurnal Inovasi Hasil Pengabdian Masyarakat (JIPEMAS), 4(1), 78-89. https://doi.org/10.33474/jipemas.v4i1.8674

Smeru. (2021). "Ringkasan Eksekutif : Dampak Sosial Ekonomi COVID-19 terhadap Rumah Tangga dan Rekomendasi Kebijakan Strategis untuk Indonesia". Berita Maret 2021. Smeru. Diakses 25 Agustus 2021 pada https://smeru.or.id/id/content/ringkasaneksekutif-dampak-sosial-ekonomi-covid-19-terhadap-rumah-tangga-dan-rekomendasi

Soetjipto, Noer. (2020). Ketahanan UMKM Jawa Timur Melintasi Pandemi Covid-19. Yogyakarta : K-Media.

Sudaryono, S., Rahwanto, E., \& Komala, R. (2020). E-Commerce Dorong Perekonomian Indonesia, Selama Pandemi Covid-19 sebagai Entrepreneur Modern dan Pengaruhnya terhadap Bisnis Offline. Jurnal Manajemen dan Bisnis, 2(2), 115. https://doi.org/10.47080/10.47080/vol1no02/jumanis 